\title{
Syakhsiyyah (Personality) In Education: Issues and Resolutions
}

\author{
Siti Nuramirah Mohd Dzul ${ }^{1}$, Mohd Mahzan Awang ${ }^{2}$, Abdul Razaq Ahmad ${ }^{3}$ \& Anuar \\ Ahmad $^{4}$ \\ ${ }^{1234}$ Faculty of Education UKM, MALAYSIA \\ E-mail: amirahdzul@gmail.com
}

\begin{abstract}
This paper discusses the issues of syakhsiyyah (personality) in education by relating to scholarly essays, theories, documents, and books with reference to the National Philosophy of Education, based on which, it can be concluded that the objective of the country's education is to produce outstanding and well-balanced individuals in terms of academic, personality, and self-identity. Hence, this paper concentrates on three issues on personality and their resolutions. Excellence in education today focuses on intellectual rather than personal as the achievement of each student is measured by the number of ' $A$ ' grades obtained in the results of examinations, especially public examinations. The dilemma is that students cannot retain academic excellence when they have poor personality. Thus, intellectual excellence alone is not sufficient to accomplish the philosophy. Holistic emphasis must be carried out to reinforce success so that everyone can reap the benefits. Through this paper, understanding about personality in education can be improved and increased.
\end{abstract}

Keywords: personality, education, students

\section{Introduction}

The aspect of syakhsiyyah (personality) in education is very important for students to promote excellence in education. Today, many students are caught up in personality-related issues that affect their academic performance even though earlier they have been regarded highly by others.

According to Syed Najmuddin et al. (2009), the government aims to develop a unique model of communitybased physical development without neglecting cultural values and virtues, and this shows that ethical aspects are prioritized in the development of the nation. Therefore, the aspect of personality should be focused from the outset, especially at the school level so that students may develop their personality early in life according to the aims of the government. Abdullah (2006) emphasised that as a preparation to face life challenges, a student should develop a high-class personality and mould his/her character to become a person of excellent knowledge and thinking in society and nation.

According to Mohd Ismail (2007), the growth of an individual personality focuses not only on the physical, inborn, and intellectual perspectives but also on the spiritual aspects as holistic and critical thinking among students needs to be cultivated and trained. 
Spiritual development is an integral part of students' lives. According to de Souza (2006), spiritual aspects can help young people to find purpose in their lives and foster a sense of self-esteem.

Through a sense of self-esteem, students will realize their potential to become the most qualified individuals through character enrichment based on good values.

Through the National Philosophy of Education (FPK) education in Malaysia is a continuous effort to develop the potential of individuals in a comprehensive and integrated way to create well-balanced and harmonious human beings intellectually, spiritually, emotionally, and physically. One of the challenges of becoming a developed nation by 2020 is to inculcate moral and ethical values in society to create an excellent society and build a holistic personal personality (Centre for Curriculum Development, 1992).

Education is the best mechanism for achieving national goals through the establishment of the National Philosophy of Education (FPK) in 1982, which acts as a benchmark in education (Habsah et al., 2009). The National Philosophy of Education (FPK) clearly emphasizes the balance of intellectual, spiritual, emotional, and physical aspects (Syed Najmuddin et. al, 2009).

Additionally, the main goal of the National Philosophy of Education (FPK) is to produce individuals who will become excellent people through educational processes that are based on trust and obedience to God (Mok Soon Sang, 2011; Habsah et al., 2009).

All of the goals listed in the philosophy indicate that student development should cover all aspects of student achievement, which is indirectly reflected in the continuation of academic excellence.

\section{The Concept of Personality}

Generally, students who have good personalities not only display good physical appearance, friendly demeanour, behaviour acceptable to the norms and values of society, selfcontrol, but also interact well with others and maintain their individual religious values. On the other hand, students who are said to have a problematic personality are more likely to have problems with discipline, deviance, drug abuse, and hold values or culture in conflict with the norms of society.

Personality refers to the tendency of an individual's behaviour. It is the manner each individual acts in their own way, which has a similar pattern every day (Siti Fatimah, 1993).
The word syakhsiyyah, which originates from the Arabic language, can be identified as a concept of personality (Kamus Dewan, 2000). According to Fitriah (2013), syakhsiyyah is the development of the character, personality traits, morals, and ethical qualities of an individual. Kagan (1988) defines personality as the overall pattern of an individual that includes the manners he/she thinks, feels, behaves, and relates to the environment.

Similarly, the definition of EE Ah Meng (1997:131) states that syakhsiyyah refers to the psychological establishment of a person as a whole.

According to Hassan (2003), syakhsiyyah is a particular system that consists of habits determining one's behaviour and distinguishes its personality from that of others. This definition indicates that syakhsiyyah is a personality that can be systematically shaped.

The concept of syakhsiyyah or personality should be inculcated and practiced by students for the well-being of family units, society, nation, and country. Students must have an excellent personality to be exemplified to maintain good morality, remain responsible, and be disciplined so that they do not fall behind in today's materialistic and luxurious advancement.

\section{Educational Concepts}

Education, whether formal, formal or semi-formal, is very important in human life. Various definitions of education can be found because the concept of education is so broad.

Education exists with human existence. According to Abdul Fatah (2007), education begins with human existence, which is when God taught the prophet Adam, who then taught his descendants the truth based on the guidance of God the Almighty.

According to Hassan Langgulung, who was cited byWan Mohd Noor (2011), education carries a specific meaning concerning human activities to preserve survival as an individual or as a member of the community. Jamal Badawiy was cited as stating that education or tarbiyyah is based on a step-by-step method of achieving perfection (Maimun Aqsha 2007).

Nevertheless, as cited by Wan Mohd. Nor (2005), al-Attas emphasizes that the purpose of Islamic education is not merely to produce good homelands and workers, but rather, to create good citizens. 
According to al-Attas, education is the process of civilizing human beings or insan adabiy (Sidek Baba 2006; Wan Mohd. Nor 2005). He further explained that education is similar to transplanting, seeding, and planting manners in someone.

Based on these concepts, it is obvious that the purpose of education is not solely on paper but to produce holistic students who balance all aspects of their life.

\section{Conceptual Descriptions of the Study}

The requirement of the study to determine the relationship between student attitudes to the three issues discussed and the formation of holistic students has resulted in the conceptual framework of the study, as shown in Figure

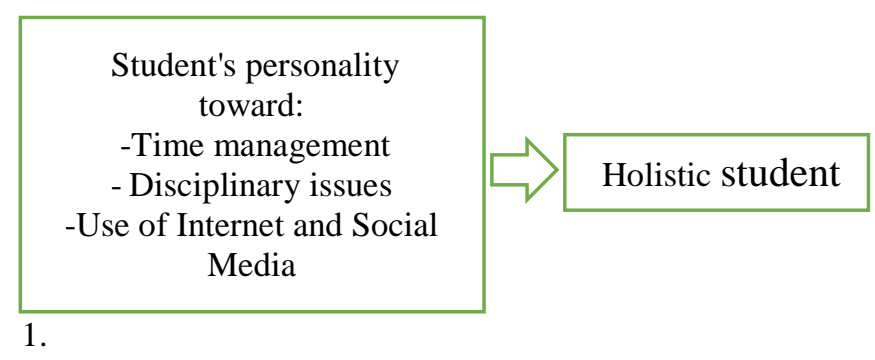

Figure 1: Conceptual descriptions of the study

\section{Personality Issue in Education}

Many students' personality-related issues occur these days. However, three issues were selected to be addressed as the decline in their academic performance was largely due to individual students' time management, disciplinary problems, and the use of the internet and social media.

\subsection{Time management}

Claessens et al. (2004) defined time management as an action that concentrates on the effective use of time while conducting activities, such as carrying out academic duties. Meanwhile, researchers such as Sansgiry et al. (2006) pointed out that time management is an important set of behaviours in learning or the course management, and excellent academic achievement can be achieved by effectively balancing time management and learning techniques.

Currently, students are found to be saying that time is not enough because they are weak in time management. This circumstance happens because some students do not know how to appreciate their time and always spend time on their own pleasures and fun. In this case, a student who manages his time well can benefit and even determine his/her excellent achievement in education.

\subsection{Disciplinary problem}

Disciplinary problem among students has been increasing lately. Some of the disciplinary issues that occur include violations of school rules, absenteeism, bullying, and others. Nowadays, some students are more likely to make different kinds of mistakes, and they are not able to tell the difference between good and bad. This is a concern for many who prioritize academic performance as students' academic achievements decline, and almost all educational institutions certainly have a record of disciplinary problems every day. Some communities will often blame educational institutions for the disciplinary problems that students have created.

Findings showing that male students are more involved in disciplinary cases are no longer valid, as recent studies have found that female students are also involved in breaking the rules (Zalizan Jelas et al., 2001, and Azizah, 2002). Besides, disciplinary problems involve students from the lower-income, middle-income, and upper-income groups (Akma \& Bhasah, 2005; Liong Lian Tai, 2006) and also, disciplinary problems are not only affected by specific institutions (Abdullah Al-Hadi et al., 2001). Consequently, it can be said that this predicament is an issue that is affecting nearly all students everywhere and from different backgrounds. This may bring negative implications to the nation as students are the future leaders and major contributors to the economy.

\subsection{The Use of the Internet and Social Media}

The Internet can harm by having negative impacts on students. Rahardian Elfan (2011: 8) points out the negative effects of misuse of the Internet, namely: a) decreasing of social attitudes, b) changing of social interaction patterns, c) criminal tendencies, d) addiction to negative things shown on the Internet. Ng \& Wiemer-hastings et al (di Park et al, 2014) state that excessive use of the Internet or misuse of the Internet can cause a variety of problems, including failure in academic performance, family problems, interpersonal problems, and physical weakness due to lack of sleep or illness. Students may lose their focus to learn when they use the Internet for non-academic purposes, such as downloading movies and participating in social media when teachers are explaining the lessons in the classroom. Also, they need to have enough money or a particular budget to buy Internet quota. They can also be addicted to the facilities provided online (Fitri, Erwinda, \& Ifdil, 2018; A. P. Sari, Ilyas, \& Ifdil, 2017). 
Several accessible pornographic sites are also among the negative effects of the internet (Asari \& Nuryna, 2011). Individuals who are addicted to pornographic videos may develop brain damage (Struthers, 2010). Besides, nonscientific contents and bad news are spread over the Internet and easily accessible to students. This can be detrimental to students as they are indifferent and not active in analysing existing information. They tend to receive incorrect information from obscure sources to be used as a reference in the lesson, which in turn makes them less efficient in carrying out their academic tasks.

\section{Proposed Solutions}

For the first issue, students need to be aware that good and effective time management is the key to their success in any area. A student's real goal is to learn and strive to succeed in education because in one sense, education alone can change one's life for the better. Therefore, various ways and methods should be carefully planned and designed to bring students toward that goal. Time management should be a personal agenda for students to achieve personal growth in their lifetime. According to Chris Croft (1996), "time management is the ability to use your time on the things that matter". Until now, we have been using the expression "Time is gold" for a long time. If the value of time is measured, it will be found that the value of time is more expensive than gold. In the time allotted to us for 24 hours a day, it should be used to do good and useful things.

According to Harold L. Taylor (1987), "Time management is a reachable goal for those who have the motivation. And you must know what you want to accomplish during your lifetime, the things that are really important to you". In this case, students need to understand how to manage time well because time management will remind students of the importance of time in their lives, and in turn, they will avoid being involved in matters that do not benefit anyone.

Mohd Najib and Yoon Weng stated that Lewis (1991) divided time management skills into five basic categories, namely human skills, planning skills, creating skill, self-motivation, and innovation. In the human skills category, students should have the capability to communicate with peers and lecturers. Planning skills also require students to be able to manage their academic and personal activities regularly. Students who have creating skills should be able to carry out planned activities without delay. The category of self-motivation requires students to motivate themselves to engage in activities, and self-motivation can be stimulated by motives and incentives. Students who fall into the innovation category should have the attitude to do something existing in a better way.

Here, the importance of time management in influencing students' academic performance can be seen. Effective time management can also prevent students from engaging in unhealthy activities such as hanging out, playing video games in entertainment centres, and so on.

Regarding the second issue, the results of a study conducted by Finn et al. (2008) and Lansford et al. (2002) found that individuals involved in disciplinary and responsibility issues are prone to more serious cases. Studies have also found that there is a significant relationship between the cognitive aspect and the frequency of disciplinary errors (Usman Ahmad Karofi, 2005). Overall, the results of studies conducted by scholars found that an individual's thinking is the origin of the selection of a course of action. The reasoning comes from the information stored in the individual's data store, which is used and processed by a person before making a decision and doing an action (Dodge, 1980). Most individuals who have limited or negatively-charged information will choose deviant and unprofitable actions (Dodge, 1993). This, in turn, will encourage individuals to make mistakes. Various methods have been worked out to solve this problem, but the best way is through thoughts intervention.

Regarding the third and final issue, individuals need to use technology, especially the Internet (Ekawati, 2012). Smartly using the Internet is related to the self-control of individuals using it (Andina, 2010). According to Averill (in Handayani N, 2015), self-control is a simple psychological variable that consists of three concepts of the ability to control oneself, the ability of individuals to adjust behaviour, control undesired information by interpreting and choosing actions according to what they believe.

Therefore, students should be able to control their use of the Internet in terms of cognitive control, behaviour, and decision making. This can be seen from the students' ability to determine the length of time they use the Internet, materials, or content to be accessed on the Internet and in choosing the facilities to be used on the Internet. Students can then use it for positive things when needed.

\section{Conclusion}

The importance of syakhsiyyah (personality) in education is significant when we emphasize the balance of all aspects holistically. Syakhsiyyah (personality) in education should be practiced in a continuous way to produce holistic students. Based on the issues mentioned earlier, it is apparent that the aspects of personality are significant to emphasize for these 
students to be successful in improving the country. The tendency to appreciate good values in life can help students improve their academic performance and contribute to their future well-being (Mumtazah Othman \& Nurizan Yahaya, 2009). The effect of placing all aspects of pure values into life will create a life full of blessings for each individual (Noor Lela Ahmad, 2008).

\section{References}

[1] Aminudin Bin Basir @ Ahmad \& Jamsari Alias (2015). Konsep Pendidikan Citra Universiti: Satu Pengenalan. MALIM - Jurnal Pengajian Umum Asia Tenggara - Vol 16: 56-67 ISSN 1511-8393 \& E-ISSN 2289-5183

[2] Azura Hamdan, Rohany Nasir, Rozainee Khairudin \& Wan Shahrazad Wan Sulaiman (2015). Perbezaan Kecemerlangan Pelajar Dari Perspektif Pengurusan Masa, Keputusan Akademik Terdahulu Dan Jantina. Jurnal Psikologi Malaysia 29 (1) (2015): 39-52 ISSN 2289-8174

[3] Elmi Baharuddin \& Zainab Ismail (2015). Kecerdasan Ruhaniah Membentuk Manusia Unggul. Islamiyyat 37(2) 2015: 97 - 105

[4] Elmi Baharuddin \& Zainab Ismail (2016). Matlamat Kecerdasan Rohaniah Menurut Perspektif Islam. Jurnal Hadhari 8 (1) (2016) 169-185

[5] Mohamad Khairi $\mathrm{Hj}$ Othman, Asmawati Suhid \& Samsilah Roslan (2015). Penghayatan Nilai Murni dalam kalangan Pelajar Sekolah Menengah Masa Kini. Jurnal Pembangunan Sosial Jilid 18 (Jun) 2015: 1-20

[6] Mohd Faiz Mohd Yaakob, Jamal@Nordin Yunus \& Hamidah Yusof (2016). Model Pengukuran Budaya Sekolah: Kajian Di Sekolah Kebangsaan Di Malaysia. Jurnal Kepimpinan Pendidikan Oktober 2016, Bil. 3, Isu 4

[7] Mohd Faiz Mohd Yaakob \& Jamal Nordin Yunus (2017). Pembinaan Dan Pengujian Kesahan Model Budaya Sekolah. Jurnal Penyelidikan Dedikasi Jilid 13, 2017

[8] Mohd Nasir Rayung, Abdul Said Ambotang \& Mohd Yusof Abdullah² (2018). Pengaruh Kecerdasan Holistik Terhadap Kemenjadian Pelajar Tingkatan Enam Di Sabah. Jurnal Kesidang Journal of Kesidang Volume 3 2018: 9-22

[9] Putri, Y. E., Daharnis, D., \& Marjohan, M. (2018). SelfControl Of Students In Using The Internet. Konselor, 7(3), 101-108. https://doi.org/10.24036/0201873101409$\underline{0-00}$

[10] Salwati Binti Mohamed@Awang \& Masliza Binti Mat Jusoh (2017). Pengurusan Masa: Faktor Kemerosotan Pencapaian Pelajar JKE Bagi Kursus Electrical Technology (DET1013). National Innovation and Invention Competition Through Exhibition (iCompEx'17)
[11] Shahidah Hamzah, Muhammad Nubli Abdul Wahab, Fauziah Ani, Zahrul Akmal Damin, Harliana Halim \& Shamsaadal Sholeh Saad (2018). Pemantapan Nilai Disiplin Melalui Kaedah Biofeedback Dalam Kalangan Mahasiswa. Pusat Pengajian Umum dan KoKurikulum, Universiti Tun Hussein Onn Malaysia, 86400 Parit Raja, Batu Pahat, Johor \& Pusat Bahasa Moden dan Sains Kemanusiaan, Universiti Malaysia Pahang, 26600, Pekan, Pahang.

[12] Shahidan Bin Shafie \& Ying-Leh Ling (2017). Pembentukan Sahsiah Berkualiti Melalui Penghayatan Kurikulum Pengajian Islam: Satu Kajian Korelasi Di Politeknik. National Conference on Thinking Culture (ICTC) 2017 01-03 November 2017

[13] Siti Fatimah Ahmad \& Maimun Aqsha Lubis (2015). Islam Hadhari Dalam Pendidikan Pembangunan Modal Insan Di Malaysia: Satu Analisa Epistimologi. Jurnal Hadhari 7 (1) (2015) 1-18

[14] Siti Solehah Binti Ibrahim (2015). Ciri Sahsiah Dalam Pemilihan Pelajar Ke Program Ulul Albab Maktab Rendah Sains MARA Gemencheh, Negeri Sembilan. Universiti Putra Malaysia

[15] Sohana Abdul Hamid \& Hairun Najuwah Jamali (2017). Komunikasi Berkesan Membina Sahsiah Pelajar. Islam Transformatif: Journal of Islamic Studies Vol.1, No.1, Januari-Juni 2017. 